\title{
Conversion of wastelands into state ownership for the needs of high-rise construction
}

\author{
Elena Ganebnykh, ${ }^{1, *}$ \\ ${ }^{1}$ Vyatka State University, Moskovskaya str., 36, Kirov, 610000, Russia
}

\begin{abstract}
High-rise construction in big cities faces the problem of land shortage in downtown areas. Audit of economic complexes showed a large volume of wastelands. The conversion of wastelands into state and municipal ownership helps in part to solve the problem of the lack of space for high-rise construction in the urban area in the format of infill construction. The article investigates the problem of the conversion of wastelands into state and municipal ownership. The research revealed no clear algorithm for converting wastelands into state and municipal ownership. To form a unified system for identifying such plots, a universal algorithm was developed to identify and convert ownerless immovable property into state or municipal ownership.
\end{abstract}

\section{Introduction}

Empirical observations have shown that high-rise residential construction is mainly distributed in the metropolitan central districts with a high density of construction. This phenomenon can be explained by the fact that traditionally downtown areas are more prestigious for living, therefore, the increased demand for housing should be provided by an appropriate proposal from the developers. However, a serious limiting factor here is the land shortage for this type of housing development. At the same time there is a large number of wastelands in cities, which is confirmed by the results of the city's economic complexes audit initiated by municipal bodies. Only in Moscow there were found 25 million square meters of wasteland [1].

The problem of wastelands is partly associated with "losses" during the restructuring of government bodies, so most often it concerns abandoned roads and green areas. A very important question is adequate consideration of the assignment of these wastelands use, since from the ecological point of view green areas should be improved and converted into park areas. However, partially abandoned wastelands can be undoubtedly given for the construction of housing stock. If such plots are located in an acceptable zone, then this will help develop high-rise construction in cities.

Though the conversion of wastelands into state or municipal ownership does not completely solve the problem of lack of land for high-rise construction in downtown areas,

\footnotetext{
* Corresponding author: ganebnykh@mail.ru
} 
it can partially provide for infill construction. At the same time, the conversion of wastelands into state (municipal) ownership with subsequent making plots over for construction is a way of the municipal budget replenishing.

The conversion of land plots into state and municipal ownership is one of the most pressing issues of land and property relations. The process of converting wasteland plots into state and municipal ownership has a number of difficulties related to the lack of a full-fledged system for identifying abandoned property - therefore, not every state and (or) municipal authority considers such work to be a wise measure.

Historically, after the "Decree on Land" in 1917, all land in Russia was automatically converted free of charge into state ownership, that is, it was seized from the owners voluntarily and expropriated, and then was included in the administrative circulation through redistribution between citizens and legal entities only based on decisions of the relevant bodies. At that time, the fundamental principles were the principles of labor land use (cultivation of land only in-house) and equalization of land in accordance with consumer and labor standards. Any transactions with land plots for their alienation (sale, lease and (or) security) were prohibited. As a result of these transformations, the State became the largest and the monopolist owner, and the leading forms of land use, corresponding to the interests of the state and society, were exclusively social (communes, partnerships, and later collective and state farms) [2]. Thus, the Soviet period ruled out the possibility of wastelands in legal terms, but in fact, wastelands always exist, especially on the territory of such a huge country.

After issuing in 1990 the RSFSR law "On Land Reform", a number of economic reforms began, which resulted in forming free market relations in Russia. The main directions of land reform in the 1990s in the Russian Federation include: reforming the legal framework; administrative redistribution of agricultural land; introduction of an economic regulation mechanism in the land and property sphere (land purchase, land payments); formation of governing bodies in land and property sphere; information support of land reform (land cadaster, land monitoring) [3].

By the end of a long ten-year period of transformation of land relations, it became clear that there was an urgent need for more rigorous codification of all changes (adoption of a new Land Code [4]), more active participation of the State as a correcting and guaranteeing institution and "generally carrying out state policies in the field of land relations targeted not at buying and selling land and its speculating, but at rational use of the land, ensuring an increase in soil fertility and yield of agricultural crop, environmental protection" [5]. The main reasons for the existence of wastelands at present stem from the processes that took place in Russia in the 1990s, namely: transition to the market economy, establishing private property, privatization of land, and formation of a new largely imperfect legislation.

\section{Materials and Methods}

To analyze the state of the problem of wastelands it is necessary to conduct a comprehensive study including the following stages:

1. Legal provisions for the conversion of wasteland plots into state and municipal ownership:

- studying the unity existing in legal understanding and terminology concerning wastelands; - studying availability and completeness of the legislative framework ensuring the identification and circulation of wasteland;

- studying procedures for converting ownerless immovable facilities into the state ownership.

2. Analysis of procedures for registration of wasteland plots in State cadastral records. 
3. Assessment of capabilities and ways of disposing wasteland plots by state and municipal authorities:

- analyzing formats for granting land to own or dispose by private individuals or legal entities; - studying the process for granting land plots to own or dispose by private individuals or legal entities;

- studying price formation when selling land plots to own or dispose by private individuals or legal entities;

4. Analysis of the practice of converting wasteland into state and municipal ownership on the example of the City of Kirov municipal entity administration:

- identifying weak points in the practice of converting wasteland plots into state and municipal ownership;

- searching for advantages for state and municipal authorities from the conversion of wastelands into their ownership.

The results of the research made it possible to work out a number of recommendations to improve the system for converting wasteland plots into state and municipal ownership, and to form an algorithm for identifying and converting ownerless property into state or municipal ownership.

\section{Results}

The research investigated and analyzed theoretical aspects of the system of converting wasteland plots into state and municipal ownership and ways of disposing such land plots after converting them into state and municipal ownership. If all idle lands on the territory of our country are put into civil circulation, this will positively affect the country economy as a whole. According to economic calculations, if all the land in Russia is either leased out or transferred into ownership, the GDP will increase by $10 \%$ per year, that is, it will be higher than that of China - through land resources alone [6].

\subsection{Legal provision for converting wasteland plots into state and municipal ownership}

According to the RF legislation [7], objects can be recognized as ownerless in 3 cases: objects do not have an owner, the owner of the object is unknown or the owner refused the object. It is important to understand that wasteland plots are considered to be only those land plots that have no owner or which owner is unknown. At the same time, land plots, where the owner refused from the right of ownership, are not classified as wasteland plots.

In most municipalities, the process for identifying ownerless immovable property is approved at the level of municipal legal acts. For example, the City of Kirov municipal entity has the Resolution of the Administration of the City of Kirov of 30.08.2017 No 3202$\mathrm{p}$ "On the approval of the Regulations on the process of registration of ownerless immovable property into the ownership of the municipal entity "City of Kirov". And this act regulates the process of converting not only wasteland plots, but all the ownerless property located on the territory of the city.

The main stages in converting wasteland plots into the state and municipal ownership include the identification of wasteland, their state registration as ownerless, as well as declaring state or municipal ownership on the wasteland plot in a judicial proceeding.

There is no definite procedure codified by law to identify ownerless property, therefore each municipality is compelled to develop such a procedure independently, based on territory peculiarities and (or) activities of the property management committees.

Practice shows that wasteland plots are identified as a result of: 
- information sent by individuals and legal entities to the territorial departments of the City or District Administration;

- notifications from the State cadastral registration authorities to the Administration about land plots without registered rights;

- incoming owner's abandonment of the land plot ownership to the local government body at the location of the land plot;

- identification of ownerless property in the course of auditing the immovable property use on the territory of a municipality conducted within the framework of municipal control.

Thus, in the course of conducting such municipal land control, the Administrations of municipal entities work to ensure compliance with the requirements of land legislation in the use of land plots in accordance with their designation, category, permitted use, as well as identify previously unrecorded land plots, and list them. The main body providing land control is a specially formed Commission.

After identifying wasteland plots and their listing, the Commission examines them directly and draws up an inspection report, which is sent to the Office of the Federal Service for State Registration, Cadaster and Cartography of the region to take essential measures. The identified wasteland plots are subject to mandatory state cadastral registration, which is carried out at the request of the local government body on which territory such plots are located.

Within a year after registering the wasteland plot, it can be returned to the owner or transferred to another person under the rule of acquisitive prescription [7]. If during this time nobody declares their rights to this land plot, then in this case it is possible to declare state or municipal ownership of the wasteland plot in a judicial proceeding on the application of state and (or) municipal authorities. Such applications are examined primarily by courts of general jurisdiction or arbitration courts.

After the court decision on recognition of the right of municipal ownership of the city, district on the land plot becomes effective, the Committee applies for state registration of the right of municipal ownership of the immovable property. The Certificate of the municipal title is issued in a month's time, and then the resolution of the City Mayor, the Head of Administration simultaneously includes the land plot in the Unified Register of the City (District) Municipal Property and excludes it from the Register of Ownerless Immovable Facilities.

\subsection{Analysis of procedures for registering wasteland plots in state cadastral records}

The process of cadastral registration of wasteland plots is regulated by the Order of the Ministry of Economic Development of Russia of 10.12.2015 N 931 "On Establishing the Procedure for Registering Ownerless Immovable Property". Governing bodies in municipal territorial entities (city and district) have the right to adopt their own statutory acts regulating issues relating to registration of ownerless immovable property, including land plots, unless otherwise stipulated by the legislation.

Thus, having analyzed the legal framework, the following process was identified for the registration of ownerless immovable property:

- taking an application for registering a land plot as wasteland with the essential documents attached;

- verifying the documents authenticity and credibility of information reflected in them;

- making entries in the Unified State Register of Immoveable Property on the registration of wasteland plots.

Depending on the territorial location of the land plot, the relevant bodies have the right to file an application: 
- if the land plot is located on the territory of an urban, rural settlement or city district, then the application is submitted respectively by local government bodies of urban, rural settlements and city districts;

- if the land plot is located in inter-settlement territories, then the application shall be submitted by the local government body of the municipal districts on which territories the land plot is located;

- if the land plot is located on the territories of cities with federal status, then the application is submitted by the executive State government bodies of these cities with federal status;

- if the land plot is located on the territory of more than one municipal entity, then the application is submitted by any local government body with reference in this case to the name of another municipal entity on which territory the immovable property object is also located.

The decision to register a land plot is expressed in making the entry of registration in the Unified State Register of Immovable Property, after which the applicant receives notification of the object registration.

\subsection{Assessment of the capabilities and ways of disposing wasteland plots by state and municipal authorities}

Land plots in state or municipal ownership are one of the main sources for replenishing the budgets of the State, region, and municipality. The main way to draw income from such land plots is to dispose them skillfully, which is carried out through using the land plot in one's own interests or by assigning land plots to use of individuals or legal entities. The general procedure for granting land plots is shown in Figure 1.

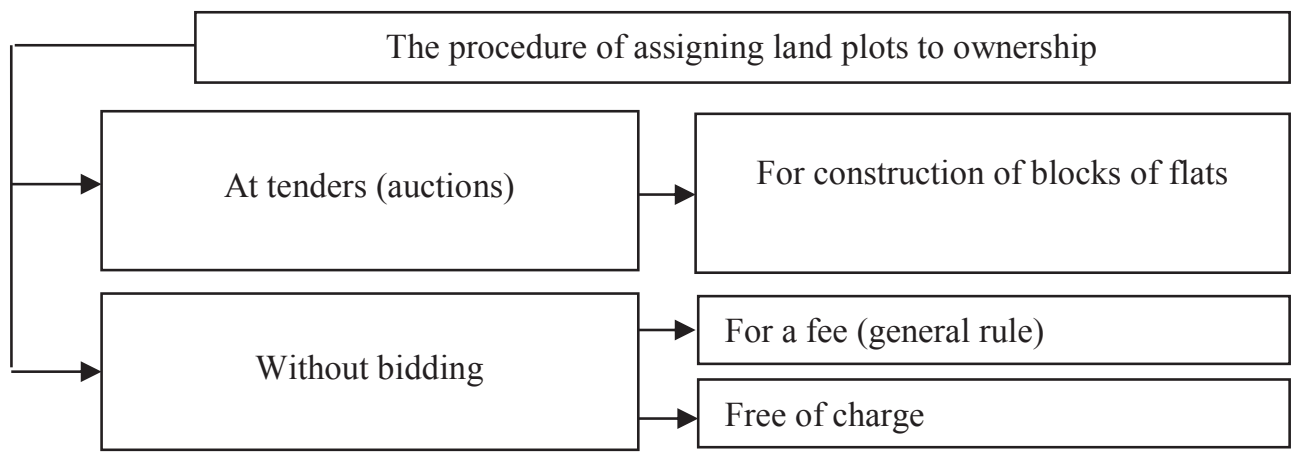

Fig. 1. General procedure of assigning land plots to ownership

According to the provisions of the Land Code of the Russian Federation, the powers to assign land plots from the state and municipal property, depending on the specific form of the land plot ownership, are given to the relevant executive bodies of state power and local government bodies.

Free assignment of land plots from the state and municipal property is carried out in the following cases:

- assigning a land plot to religious organizations;

- assigning a land plot to a non-profit organization of citizens established for gardening, truck farming and related to communal facilities;

- assigning a land plot to a citizen who has used it in accordance with the established permitted use for the right of uncompensated use for 5 years;

- assigning a land plot to citizens with 3 or more children;

- assigning a land plot to certain categories of citizens. 
In other cases, land plots are provided on a paid basis. Therefore, forming land prices is of particular importance, since the receipts are revenues of budgets of the corresponding levels. The formation of the transaction price of the land plot of the state or municipal ownership is shown in Figure 2.

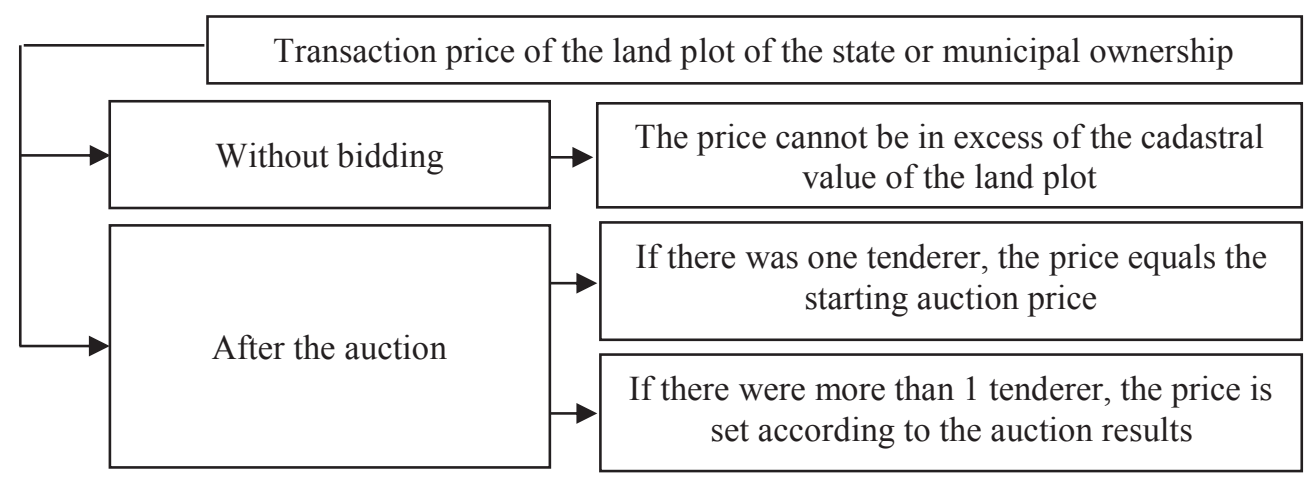

Fig. 2. Price formation of land plots of the state or municipal ownership

The procedure for auctioning the ownership of a land plot of the state or municipal ownership depends on the initiator of the auction (a party concerned or authorities) and on the auction organizer (the authorized government body or a specialized organization acting on the basis of a contract with the authorized government body).

Thus, Russian legislation establishes and regulates many ways to manage state and municipal lands. Choosing the way of disposal lies entirely with the authorized state and municipal authorities.

\subsection{Analysis of the practice of converting wasteland plots into state and municipal ownership on the example of the City of Kirov municipal entity administration}

Analyzing data available from the official websites of the Administration of the City of Kirov, it becomes evident that the process of converting ownerless property into state and municipal ownership in the Kirov region is poorly developed. Local government bodies are mainly engaged in converting into municipal ownership such ownerless immovable objects as ownerless flats, ownerless houses, as well as ownerless engineering communications. Conversion of wasteland plots into municipal ownership is quite a rare phenomenon. This situation is typical for most municipalities due to a number of reasons.

1. The complexity of the procedure for converting wasteland plots. As a result of constant updating of the regulatory and legal framework, which, on the one hand, improves and regulates certain issues more clearly, but, on the other hand, changes too often, all processes slow down because specialists need time to understand and produce a system for applying these norms in practice.

2. Lack of clear delimitation of duties of government bodies in this issue. The law does not stipulate that it is the duty of municipalities to register rights to the ownerless property, therefore, using this fact local government bodies do not undertake such duties. On the other hand, the law says that the only authorities that have the right to file an application for registering ownerless property are local government bodies, since only they have the right to apply to the registration authority to register such property in cadastral records [8]. 
3. Absence of a clear algorithm of actions to convert wastelands into state and municipal ownership. Currently, there is no general provision regulating the procedure for converting wasteland plots into state and municipal property. Therefore, as a rule, local government bodies establish this procedure.

4. Lack of a clear system for identifying wasteland plots. The procedure for identifying ownerless property is not regulated by any general statutory act either. The legislative base is all the same Decisions and Regulations of local government bodies, which do not provide a clear procedure for identifying ownerless property [9].

5. Weak interest of the authorities in converting wastelands into state and municipal ownership. This process can be described as costly and protracted, as, firstly, to obtain documents with the description of the land plot, it is necessary to complete cadastral work. Only a qualified cadaster engineer has the right to conduct such work, so his work must be paid by the customer. The duration of this process is stipulated by the legislation, which states that it must take at least one year from the moment of registering a wasteland plot in the cadastral records till the moment it is recognized as municipal or state property. This time allows the possibility that the owner of this land may show up. In this case, the municipality will not be able to register the ownership of this plot.

Thus, analyzing the possible unfavorable development of the situation, the authorities do not consider this procedure viable. In practice, in order to avoid a protracted process of converting wastelands, heirless property, or unclaimed land shares into state and municipal ownership, as well as extra costs, local government bodies often write official papers stating that this land plot is not ownerless but is in the municipal ownership or that the data on the rights to the land plot, the owner of which has died, are registered in the Unified State Register of Real Estate by mistake, since authorized bodies haven't issued any certificate on the right to life (inherited) possession or the right to permanent (unlimited) use [10].

Nevertheless, the advantages of converting ownerless property into state and municipal property are also evident. Firstly, the number of municipal or state immovable property objects is growing for a minimal fee, which can be used for their own purposes[11]. Secondly, it becomes possible to expand and replenish the tax base due to ownerless immovable property, which leads to an increase in taxes incoming to the state budget.

Thus, having analyzed the system of converting wasteland plots into state and municipal property, there was revealed a large number of shortcomings and defects. At the same time, the advantages of the system are revealed in the possibilities of disposing converted land plots, this system is particularly favorable for housing construction lands, as it incurs significant revenues to the budget.

\section{Discussion}

As a result of the research, the following important aspects of the system of converting wasteland plots into state and municipal property were revealed:

- need to secure duties of implementing and monitoring the process of identifying ownerless property, respectively, to state authorities or local government bodies (delineation of levels of responsibility);

- need to allocate responsibility for dealing with ownerless property, located on the municipal territory, to the Head of administration of this municipality (personal responsibility);

- availability of a clearly-defined algorithm of actions to identify and transfer ownerless property into state or municipal ownership (uniform procedure).

The results of the research made it possible to formulate a number of recommendations on improving the system of converting wasteland plots into state and municipal property. 
Identifying and listing wasteland plots

\begin{tabular}{|c|c|c|c|c|c|c|}
\hline \multicolumn{7}{|c|}{ Identifying and listing wasteland plots } \\
\hline \multicolumn{2}{|c|}{$\begin{array}{l}\text { On application of } \\
\text { individuals and legal } \\
\text { entities }\end{array}$} & \multicolumn{3}{|c|}{$\begin{array}{c}\text { Through cooperation with } \\
\text { cadastral registration } \\
\text { bodies }\end{array}$} & \multicolumn{2}{|c|}{$\begin{array}{l}\text { As a result of municipal } \\
\text { land audit }\end{array}$} \\
\hline \multicolumn{7}{|c|}{$\downarrow$} \\
\hline \multicolumn{7}{|c|}{ Inspection of the land plot and drawing up the inspection act } \\
\hline \multicolumn{7}{|c|}{ 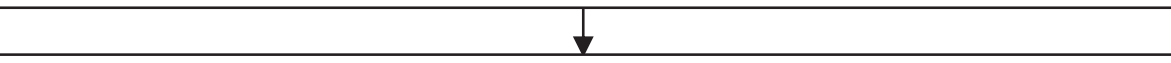 } \\
\hline \multicolumn{7}{|c|}{ Confirmation of wasteland plot status through letters of inquiry to } \\
\hline 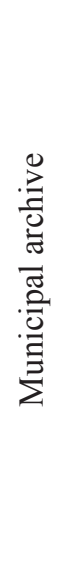 & 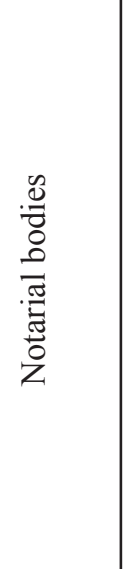 & 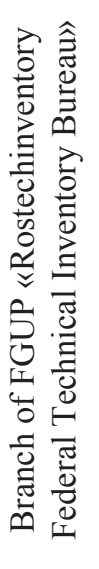 & 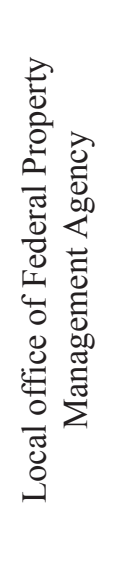 & 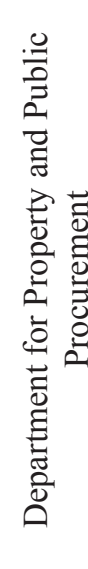 & 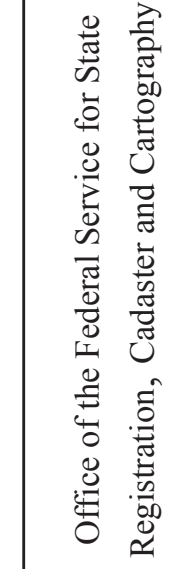 & 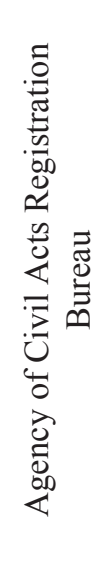 \\
\hline \\
\hline \multicolumn{7}{|c|}{ Surveying wasteland plots } \\
\hline \multicolumn{7}{|c|}{ Registering land plots in the state cadastral records } \\
\hline
\end{tabular}

Filing a claim in court (after expiry of one year time since the date of registering land plots in the state cadastral records)

Registering the land plot in the Cadaster of state and municipal property

Fig. 3. The uniform algorithm of actions for identifying and converting ownerless property into state or municipal ownership

Firstly, it is necessary to impose the responsibility for converting ownerless property on the Heads of Administrations of the respective municipalities by securing this item in the regulatory framework. This measure will stimulate local authorities to implement these activities. Secondly, it is necessary to create and legislatively fix a permanent Commission, which will be engaged in identifying previously unregistered land plots, as well as their listing. Thirdly, it is necessary to oblige local authorities to report regularly on the progress in identifying, examining and converting wasteland plots of the municipalities in question. This measure will help to systematize the results of the work performed, as well as monitor 
the process. Fourthly, it is necessary to introduce a uniform algorithm for identifying and converting ownerless property into state or municipal property. The algorithm proposed for implementation is shown in Figure 3.

This algorithm clearly shows the options for identifying wastelands. It is proposed to add to the generally accepted procedure of converting wastelands a compulsory a survey of the land plot and to draw up the inspection report. This measure will help to study the land plot and its condition, determine its potential purpose, and also make sure that this land plot is not really used and in the process of its conversion there will be no person claiming this land on the basis of acquisitive prescription. Among other things, the algorithm determines all possible organizations, which may possess information about rights, or the lack of rights to the surveyed land. Responses to letters of inquiry to these organizations are basic documents confirming the lack of registered rights to this land plot, or lack of data on such rights. These documents will form the evidence base used in court. The other stages correspond to the generally accepted system.

\section{Conclusions}

After studying the history of land and property relations, it became obvious that the problem of wastelands can be traced back for a long historical period. The wasteland of our time is a direct consequence of the events that took place during the collapse of the USSR and the formation of the Russian Federation. Until now, in the legislation there is no clear regulation of converting wastelands, which causes the complexity, high labor input and cost of this process. The research studied and analyzed theoretical aspects of the system of converting wasteland plots into state and municipal ownership and ways of disposing such land plots after converting them into state and municipal ownership.

In general, there are active attempts to form a regulatory and legal framework that, on the one hand, is improved and regulates certain issues more clearly, on the other hand, changes too often. In this connection, all processes slow down because specialists need time to understand and develop a system for applying such norms in practice.

Analysis of the practice of converting wastelands on the example of the city of Kirov municipal entity administration showed that in fact there is no clear delimitation of duties of government bodies in this issue, and there is also no clear algorithm for converting wastelands into state and municipal property. To form a unified system for identifying wasteland plots, a universal algorithm was developed to identify and convert ownerless property into state or municipal property.

The results of the research made it possible to formulate a number of recommendations for improving the system of converting wasteland plots into state and municipal property, as there was revealed a weak interest of the authorities in solving this problem.

Despite the fact that the conversion of wastelands into state or municipal property does not completely solve the problem of lack of land for high-rise construction in downtown areas, it can partially help in the format of infill construction. At the same time, the conversion of wastelands into state (municipal) ownership with subsequent making plots over for construction is a way of the municipal budget replenishing. In this regard, it will be relevant to study price formation on land plots allocated for high-rise construction.

\section{References}

1. S. Ryazanov,. Mayor fights with ghosts // Arguments of the week. 24 (2011)

2. E.Smirnova, E.A. Actual problems of the humanities and natural sciences, 4,. 158-162 (2016) 
3. V. Zasyad-Volk, Administrative consulting, 4, pp. 107-117(2011)

4. The Land Code of the Russian Federation of 25.10.2001.

5. Volkov, S.N. Land relations in Russia: materials of the round table // Economics of Agriculture, 10, 10-11(1998).

6. URL: https://www.ikirov.ru/news/29780-chto-nam-nesyot-zemelnaya-reforma (reference date: 1.11.2017).

7. Civil Code of the Russian Federation. from 30.11.1994.

8. Yu. Kulagina, Municipal Economy, 2, 90-83 (2016)

9. A. Mottaeva et al , MATEC Web of Conferences, 07018,DOI: https://doi.org/10.1051/matecconf/20167307018 (2016)

10. A.Pimenova, et al, MATEC Web of Conferences, 73, 07018 DOI: https://doi.org/10.1051/matecconf/20167307018 (2016)

11. A.Mottaeva, N.Gritsuk, MATEC Web of Conferences, 08083, DOI: https://doi.org/10.1051/matecconf/20167308083 (2017) 